О. М. Попова ${ }^{1}$, к.б.н., доцент,

I. В. Абрашкіна' ${ }^{2}$ вчитель-методист,

Т. С. Буракова ${ }^{1}$, студентка

${ }^{1}$ Одеський національний університет імені I. I. Мечникова, кафедра ботаніки вул. Дворянська, 2, Одеса, 65082, Україна

2Загальноосвітня школа № 2

вул. Бендерська, 28, Ізмаїл, Одеська обл., 68600 Україна

\title{
ДЕНДРОФЛОРА ІЗМАЇЛЬСЬКОЇ ФОРТЕЦІ (М. ІЗМАЇЛ, ОДЕСЬКА ОБЛАСТЬ, УКРАЇНА)
}

\begin{abstract}
Проаналізовано видовий склад деревних та напівдеревних рослин, які зростають на території фортеці. Наведено список дендрофлори, який охоплює 67 видів 351 роду та 31 родини. Провідними родинами є Rosaceae та Oleaceae, провідними родами - Acer та Tilia. Дерев у 1,6 рази більше, ніж кущів. Частка адвентивних для України видів становить 63 \%. Рослини мають різноманітні корисні властивості, інформацію про які слід використовувати в екскурсійній діяльності на території фортеці. Знайдено 3 види, занесені до Червоного списку МСОП, стан яких у природних місцезростаннях (поза межами України) наближується до загрозливого (Aesculus hippocastanum, Juglans regia, Platycladus orientalis). Також зафіксовано 13 видів, які в Україні є спонтанними адвентофітами, 3 них 4 види 3 високою інвазійною спроможністю та два видитрансформери.
\end{abstract}

Ключові слова: дендрофлора, Ізмаїл, Одеська область

Вивчення рослинного покриву територій міст, дослідження його сучасного стану та тенденцій змін $є$ актуальними проблемами сучасності. Суттєвим компонентом рослинного світу урбанізованих територій $\epsilon$ деревна рослинність. Деревні насадження у населених пунктах покращують мікроклімат, виконують значну санітарно-гігієнічну, естетичну, освітньо-виховну, пізнавальну, а часто i історико-культурну функції. Особливо це відчувається на півдні України, де практично всі деревостани мають штучне походження. Вивчення різноманітності деревних рослин, які зростають у жорстких кліматичних умовах, де немає природного лісу, дозволяє уточнити асортимент видів, рекомендованих для озеленення у відповідних кліматичних районах, особливо в умовах глобальних змін клімату.

Особливої уваги на території міст заслуговують історичні пам'ятки, які потребують всебічного вивчення, в тому числі і рослинного світу. Одними з таких пам'яток $€$ фортеці, які на півдні України дали початок сучасним містам і $€$ найбільш старими урбанізованими територіями міст. Якщо ліхенофлора фортець вивчається досить активно, то дослідженнями видового складу судинних рос- 
лин охоплена значно менша кількість фортець. Нам вдалося знайти інформацію про вивчення флористичного різноманіття лише деяких фортець Північного Заходу Росії [6-9].

Ізмаїльська фортеця розташована на лівому березі Кілійського рукава р. Дунай, у південно-західній частині сучасного міста Ізмаїл на площі 170 га. Вона має більше ніж 200-річну історію. До нашого часу сама фортеця не збереглася, у зв'язку з тим, що після російсько-турецької війни 1853-1856рр. за умовами Паризького мирного договору їі вали та інші укріплення були підірвані і зриті. Але тут збереглися пам'ятки воєнної і культової архітектури XVI-XIX ст. (мечеть пророка Мухамеда, яка є єдиною майже повністю збереженою пам'яткою османської храмової архітектури у всьому Північно-Західному Причорномор'ї, Успенська, Миколаївська церкви), залишки господарських, культових, жилих комплексів (під шаром грунту), численні військові і цивільні поховання. Історичну цінність має і природний ландшафт, який частково зберігся з XVIII ст. $[2,10,15]$. Зараз територія Ізмаїльської фортеці $є$ пам'яткою історії і археології. Тут існує Меморіальний парк-музей «Фортеця»; у приміщенні мечеті пророка Мухамеда розміщена діорама «Штурм фортеці Ізмаїл», яка включена у туристичні маршрути півдня України та програму міжнародного круїзу по Дунаю «Від Альп до Чорного моря». Співробітниками парку-музею розроблений текст історичної екскурсії по території фортеці [10]. Доцільним видається врахування у туристичних маршрутах і особливостей зеленого вбрання території.

Останнім часом пам’ятку археології «Культурний шар Ізмаїльської фортеці» пропонується визначати як комплексну пам’ятку археології, історії, архітектури та містобудування [2]. До поняття містобудування входить і благоустрій території, складовою якого є зелені насадження.

Таким чином, вивчення рослинного світу Ізмаїльської фортеці $є$ актуальним 3 різних позицій. Але до цього часу він не вивчався. Тому метою даної роботи було визначення сучасного різноманіття деревних рослин фортеці Ізмаїл. Завдання включали систематичний, біоморфологічний, географічний, господарський, созологічний аналіз дендрофлори та виявлення видів, які становлять біологічне забруднення.

\section{Місце та методика досліджень}

За геоботанічним районуванням України місто Ізмаїл знаходиться в Дунайсько-Дністровському окрузі злакових та полиново-злакових степів і плавнів, що входить до складу Чорноморсько-Азовської степової підпровінції Понтичної степової провінції Степової підобласті (зони) Євразійської степової області [11].

Грунтовий покрив території представлений чорноземами південними слабогумусованими міцелярно-висококарбонатними пилувато-середньосуглинковими на лесових суглинках [3]. 
Клімат району посушливий, 3 нестійкою зимою та жарким літом, недостатніми опадами. За агрокліматичним районуванням України, територія відноситься до суворо посушливої агрокліматичної зони з гідротермічним коефіцієнтом 0,5-0,7, сумою активних температур $3000-3700{ }^{\circ} \mathrm{C}$, кількістю опадів 415 мм на рік, 200-280 мм - за теплий період року, тривалістю періоду активної вегетації рослин 175-190 днів, тривалістю безморозного періоду на поверхні грунту 155-210 днів. Запаси продуктивної вологи у метровому шарі грунту на початку вегетації становлять 110-160 мм, наприкінці вегетації 50-90 мм. При цьому повторюваність атмосферної помірної посухи становить 44-55 днів на рік, суворої - 20-40 днів, також спостерігаються суховії у кількості 1-20 днів за рік [11].

Обстеження загальнодоступної території фортеці Ізмаїл проведено восени 2014 р. маршрутним методом. Обсяг дендрофлори розглядався відповідно до основних літературних джерел $[1,4]$. До обліку включені рослини віком більше ніж 20 років, у зв'язку з тим, що значна кількість насаджених останніми роками дерев і кущів масово відмирають через брак догляду (поливу). Види рослин визначали за відповідною літературою $[1,12,17,18]$. Наукові назви рослин та обсяг родин наведені за відомим чеклістом [20], українські назви видів - за визначником [4] та М.А. Кохном [12]. Життєві форми визначали за власними спостереженнями. Ареал кожного виду, встановлений за літературними даними, був віднесений до певних флористичних областей відповідно до флористичного районування Земної кулі [16]. Охоронний статус видів виявляли відповідно Червоної книги України [19] та бази даних Червоного списку Міжнародного союзу охорони природи (МСОП) версії 2015 року [21]. Синантропні, адвентивні види, види з особливо високою інвазійною спроможністю, види-трансформери встановлювали за літературними даними $[13,14]$.

\section{Результати досліджень}

При обстеженні території фортеці Ізмаїл було зафіксовано 67 видів деревних та напівдеревних рослин, які відносяться до 51 роду і 31 родини, двох класів та двох відділів вищих рослин. Це значно більше, ніж на території 11 фортець Північного Заходу Росії [6-9]. Це можна пояснити активною діяльністю людини зі створення зелених насаджень в Ізмаїльській фортеці та її значно більшою площею. Нижче наводимо перелік знайдених видів.

1. Acer monspessulanum L. - Клен трилопатевий

2. Acer negundo L. - Клен ясенолистий

3. Acer platanoides L. - Клен гостролистий

4. Acer pseudoplatanus L. - Клен несправжньоплатановий

5. Acer tataricum L. - Клен татарський

6. Aesculus hippocastanum L. - Гіркокаштан звичайний

7. Ailanthus altissima (Mill.) Swingle - Айлант найвищий 
8. Amorpha fruticosa L. - Аморфа кущова

9. Berberis vulgaris L. - Барбарис звичайний

10. Betula pendula Roth - Береза повисла

11. Buxus sempervirens L. - Самшит вічнозелений

12. Campsis radicans (L.) Seems - Кампсис повзучий

13. Celtis occidentalis L. - Каркас західний

14. Cerasus avium (L.) Moench - Черешня

15. Cerasus vulgaris Mill. - Вишня звичайна

16. Clematis jackmannii Moore - Ломиніс Жакмана

17. Cotinus coggygria Scop. - Скумпія звичайна

18. Elaeagnus angustifolia L. - Маслинка вузьколиста

19. Forsythia suspensa (Thunb.) Vahl - Форзиція плакуча

20. Forsythia viridissima Lindl. - Форзиція зелена

21. Fraxinus excelsior L. - Ясен звичайний

22. Fraxinus lanceolata Borkh. - Ясен ланцетний

23. Gleditsia triacanthos L. - Гледичія колюча

24. Hedera helix L. - Плющ звичайний

25. Hibiscus syriacus L. - Гібіск сірійський

26. Hydrangea arborescens L. - Гортензія деревовидна

27. Juglans regia L. - Горіх грецький

28. Juniperus virginiana L. - Яловець віргінський

29. Ligustrum vulgare L. - Бирючина звичайна

30. Lonicera periclymenum L. - Жимолость витка

31. Lonicera tatarica L. - Жимолость татарська

32. Lycium barbarum L. - Повій звичайний

33. Mahonia aquifolium (Pursh) Nutt. - Магонія падуболиста

34. Malus domestica Borkh. - Яблуня домашня

35. Morus alba L. - Шовковиця біла

36. Persica vulgaris Mill. - Персик звичайний

37. Philadelphus microphyllus Gray - Садовий жасмин дрібнолистий

38. Picea abies (L.) H. Karst. - Ялина європейська

39. Pinus pallasiana D. Don - Сосна кримська

40. Platanus occidentalis L. - Платан західний

41. Platycladus orientalis (L.) Franco - Широкогілочник східний

42. Populus $\mathrm{x}$ canadensis Moench - Тополя канадська

43. Prunus divaricata Ledeb. - Слива розлога, алича

44. Prunus domestica L. - Слива домашня

45. Robinia pseudoacacia L. - Робінія звичайна

46. Rosa chinensis Jacq. - Троянда китайська

47. Rubus caesius L. - Ожина сиза

48. Rubus idaeus L. - Малина звичайна

49. Salix alba L. - Верба біла 
50. Salix fragilis L. - Верба ламка

51. Salix matsudana Koidz. - Верба Матсудина

52. Sambucus nigra L. - Бузина чорна

53. Sophora japonica L. - Софора японська

54. Sorbus aucuparia L. - Горобина звичайна

55. Spiraea x vanhouttei (Briot) Zabel - Таволга Вангутта

56. Swida australis (C.A. Mey.) Pojark. ex Grossh. - Свидина південна

57. Syringa vulgaris L. - Бузок звичайний

58. Tamarix ramosissima Ledeb. - Тамарикс галузистий

59. Tilia begoniifolia Steven - Липа бегонієлиста

60. Tilia cordata Mill. - Липа серцелиста

61. Tilia europaea L. - Липа європейська

62. Tilia tomentosa Moench - Липа повстиста

63. Ulmus laevis Pall. - В'яз гладкий

64. Ulmus pumila L. - B'яз низький

65. Viburnum opulus L. - Калина звичайна

66. Vinca minor L. - Барвінок малий

67. Yисca smalliana Fernald - Юкка Смолла

Відміною Ізмаїльської фортеці від фортець Північного Заходу Росії є також незначна частка спонтанних видів (7,5 \% проти 44,7-100,0 \% [6-9]), що пояснюється ії розташуванням у степовій зоні, у той час як фортеці, 3 якими проводиться порівняння, побудовані у лісовій, навіть тайговій, зоні. Найбільша кількість видів входить до складу родин Rosaceae (11 видів), Oleaceae (6) та Aceraceae (5 видів); три родини мають по 4 види (Caprifoliaceae, Salicaceae, Tiliaceae); дві - по три види (Fabaceae, Ulmaceae); ще чотири - по два види (Berberidaceae, Cupressaceae, Hydeangeaceae, Pinaceae) та 20 родин є одновидовими. Провідними родами є Acer 35 та Tilia - 4 видами.

Аналіз життєвих форм виявив на дослідженій території 39 дерев, 24 кущі та 4 напівкущів, тобто дерев у 1,6 разів більше, ніж кущів (рис. 1). Напівкущами є Clematis jackmannii, Rubus caesius, $R$. idaeus та Vinca minor.

Географічний спектр дендрофлори свідчить про переважання циркумбореальних видів (табл. 1), також помітна участь середземноморських, ірано-

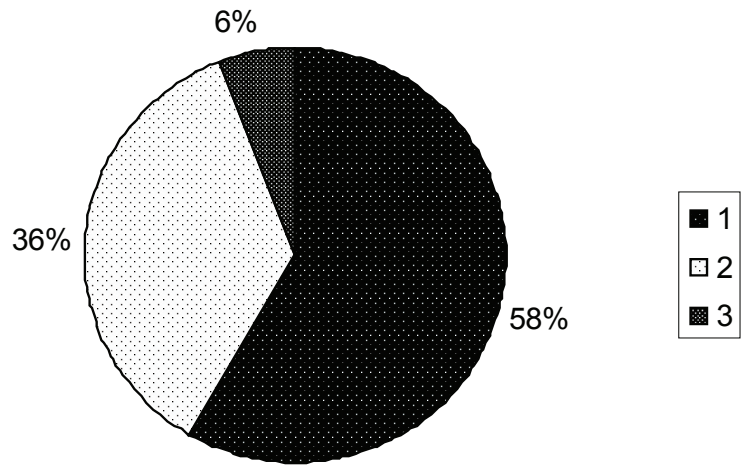

Рис. 1. Спектр життєвих форм дендрофлори Ізмайльської фортеці. Умовні позначення: 1 - дерева, 2 - кущі, 3-напівкущі 
туранських та американських рослин. Східноазійських видів вдвічі менше, ніж середземноморських та ірано-туранських, що, за нашими даними, є відміною від багатьох інших об'єктів озеленення, де східно-азійські та атлантично-північноамериканські види переважають середземноморські та ірано-туранські.

Таблиця 1

Географічний спектр дендрофлори Ізмаїльської фортеці

\begin{tabular}{|c|c|c|}
\hline Флористичні області [16] & $\begin{array}{l}\text { Кількість } \\
\text { видів }\end{array}$ & $\begin{array}{l}\text { Частка від загальної } \\
\text { кількості видів, \% }\end{array}$ \\
\hline \multicolumn{3}{|c|}{ Голарктичне царство } \\
\hline Циркумбореальна & 26 & 38,8 \\
\hline Східно-Азійська & 8 & 11,9 \\
\hline Атлантично-Північно-Американська & 12 & 17,9 \\
\hline Скелястих гір & 1 & 1,5 \\
\hline Середземноморська & 17 & 25,4 \\
\hline Ірано-Туранська & 17 & 25,4 \\
\hline Мадреанська & 2 & 3,0 \\
\hline \multicolumn{3}{|c|}{ Палеарктичне царство } \\
\hline Гвінео-Колголезьська & 1 & 1,5 \\
\hline Індійська & 1 & 1,5 \\
\hline
\end{tabular}

Найбільший інтерес у туристів викликає практичне значення рослин. Виявлено, що всі деревні рослини Ізмаїльської фортеці є декоративними і можуть використовуватися при озелененні місцевості. Лікарські властивості мають 52 видів (77,6 \%). Досить багато у фортеці медоносних (38 види, 56,7 \%), кормових (29 види, 43,3 \%), харчових (27 види, 40,3 \%), олійних (25 вид, 37,3 \%), видів. Помітна участь рослин з вітамінними (22 види, 32,8 \%), дубильними та фарбувальними (по 20 видів, 29,9 \%) характеристиками. Також зафіксовано 10 волокнистих (14,9\%), 9 отруйних (10,0 \%) та 3 камеденосні рослини $(4,5 \%)$. У 30 видів $(44,8 \%)$ використовується деревина. Практичне значення деяких видів дуже велике через можливість використовувати їх у багатьох напрямках (наприклад, Betula pendula, Sorbus aucuparia, Tilia cordata). Особливої уваги заслуговують отруйні певною мірою види, які становлять небезпеку для людини (Aesculus hippocastanum, Ailanthus altissima, Cotinus coggygria, Hedera helix, Ligustrum vulgare, Lonicera tatarica, Lycium barbarum, Sophora japonica).

На території Ізмаїльської фортеці серед рослин віком більше ніж 20 років видів з Червоної книги України не виявлено, але тут зростають 10 видів 
(16,9 \%), які занесені до Червоного списку МСОП, при цьому стан 3 видів in situ близький до загрозливого (NT): Aesculus hippocastanum, Juglans regia, Platycladus orientalis. Інші рослини викликають найменше занепокоєння (LC): Betula pendula, Juniperus virginiana, Picea abies, P. pallasiana (як P. nigra subsp. pallasiana), Robinia pseudoacacia, Salix alba, Tamarix ramosissima.

На території фортеці Ізмаїл серед штучно висаджених рослин наявні 13 адвентивних видів, які зростають спонтанно в Україні [13]. Це становить 19,4 \% дендрофлори. Майже всі вони є кенофітами (занесені до України після XVI ст.). Це такі рослини, як Acer negundo, Ailanthus altissima, Amorpha fruticosa, Cerasus vulgaris, Cotinus coggygria, Elaeagnus angustifolia, Magonia aguifolium, Morus alba, Prunus divaricata, Robinia pseudoacacia, Rubus idaeus, Salix fragilis (археофіт), Syringa vulgaris. Чотири з них характеризуються високою інвазійною спроможністю: Elaeagnus angustifolia активно поширюється в усіх районах Північного Причорномор'я, Amorpha fruticosa - в окремих районах, Ailanthus altissima - вузьколокально, а Acer negundo - потенційно активний вид у даному регіоні. Два види - Elaeagnus angustifolia та Amorpha fruticosa також відносять до видів-трансформерів, які активно перетворюють умови існування [14]. На території фортеці зафіксовано успішне самовідновлення Celtis occidentalis, Gleditsia triacanthos, Robinia pseudoacacia.

\section{Висновки}

На території фортеці Ізмаїл зростає 67 видів деревних рослин, які відносяться до 51 роду та 31 родини. Провідними родинами є Rosaceae (11 видів) та Oleaceae (6 видів), провідними родами - Acer (5 видів) та Tilia (4 види).

В озелененні території переважають дерева: їх у 1,6 разів більше, ніж кущів. Напівкущі представлені чотирма видами.

Більшість видів дендрофлори має циркумбореальне походження, другеп'яте місця займають середземноморські, ірано-туранські та американські рослини відповідно. Частка іноземних видів становить $63 \%$, що наближується до цифри, встановленої для південних міст України загалом (70 \%) [5].

Всі представники дендрофлори фортеці характеризуються корисними властивостями. Виявлено 10 деревних видів із Червоного списку МСОП, з них три види у природних місцезростаннях мають статус, близький до загрозливого, інші занепокоєння не викликають.

У дендрофлорі Ізмаїльської фортеці зафіксовано 13 адвентивних видів, чотири 3 них характеризуються високою інвазійною спроможністю, два $є$ трансформерами.

Таким чином, дендрофлора Ізмаїльської фортеці включає як особливо цінні рослини, так і потенційно небезпечні види. Перші слід охороняти, за останніми слід здійснювати постійний моніторинг. Інформацію про деревні рослини доцільно використовувати у екскурсійній діяльності на території фортеці. 


\section{Список використаної літератури}

1. Деревья и кустарники СССР. - Т. 1 - 6. - М. - Л., Изд-во АН СССР, 1949 - 1962.

2. Історико-містобудівні дослідження м. Ізмаїла // Історико-містобудівні дослідження: Васильків, Вінниця, Горлівка, Ізмаїл / За ред. В.В. Вечерського. - К., НДІ пам’яткоохоронних досліджень, 2011. C. $79-118$.

3. Карта грунтів Української РСР. Одеська область. - К.: Ін-т «Укрземпроект», 1973. - 1 к. (М 1:200 000).

4. Кохно М. А. Каталог дендрофлори України / М. А. Кохно. - К.: Фітосоціоцентр, 2001. - 72 с.

5. Кохно М. А. Дендрофлора міст півдня України / М. А. Кохно, С. І. Кузнецов, О. К. Дорошенко, П. Я. Чуприна, А.О. Пасічний // Укр. ботан. журн. - 1983. - Т. 40, № 5. - С. 12-14.

6. Мальшева Н. В. Растения средневековых крепостей северо-запада России. 1. Крепости Ленинградской области / Н. В. Малышева // Ботан. журн. - 1999. - Т. 84, № 10. - С. 46-58.

7. Малышева Н. В. Растения средневековых крепостей северо-запада России. 2. Псковский и Новгородский кремли / Н. В. Малышева // Ботан. журн. - 2000. - Т. 85, № 10. - С. 42-52.

8. Мальшева Н. В. Растительный мир крепости Орешек (Шлиссельбургской) и его изменения с IV по XX век / Н. В. Малышева, Г. П. Игнатьева, А. Н. Кирпичников // Краеведческие записки. Исследования и материалы. - Вып 5.- СПб.: 1997. - С. 38-50.

9. Мальшева Н. В. Растительный мир Санкт-Петербургской (Петропавловской) крепости и его изменения за три столетия / Н. В. Малышева // Краеведческие записки. Исследования и материалы. Вып. 6. Фортификация и архитектура Петропавловской крепости. - СПб.: 1998. - С. 305-313.

10. Мемориальный парк-музей «Крепость» [Електронний ресурс]. - Режим доступу: http://www.izmail.rada. gov.ua/sovet/images/files/park_muzey.doc 2014

11. Національний атлас України. Київ: ДНВП «Картографія», 2009. - 440 с.

12. Определитель высших растений Украины / Д. Н. Доброчаева, М. И. Котов, Ю. Н. Прокудин и др. - К.: Наук. думка, 1987. - 548 с.

13. Протопопова В. В. Інвазійні види у флорі Північного Причорномор'я / В. В. Протопопова, М. В. Шевера, С. Л. Мосякін, В. А. Соломаха, Т. Д. Соломаха, Т. В. Васильева, С. П. Петрик - К.: Фітосоціоцентр, 2009. $-56 \mathrm{c}$.

14. Протопопова B. B. Синантропная флора Украины и пути её развития / В. В. Протопопова. - К.: Наук. думка, 1991. - 204 с.]

15. Сапожников И. В. Здание мечети пророка Мухаммеда в Измаиле: новые факты и интерпретации / И. В. Сапожников // Материалы по археологии Северного Причерноморья. - 2009. - Вып. 9. - С. $243-268$.

16. Тахтаджян А. Л. Флористические области Земли / А. Л. Тахтаджян. - Ленинград: Наука, 1978. - 274 с.

17. Флора Восточной Европы. Т. 9 - 11. - С.-Пб., 1996-2004.

18. Флора Европейской части СССР. - Т. 1-8. - Л. - 1974-1994.

19. Червона книга України. Рослинний світ / за ред. Я.П. Дідуха. - К.: Глобалконсалтинг, 2009. - 912 с.

20. Mosyakin S. L., Fedoronchuk M. N. Vascular plants of Ukraine. A nomenclatural checklist. Kiev: 1999. - 346 p.

21. The IUCN Red List of Threatened Species. - 2015.2. - Режим доступу: http://www.iucnredlist.org

Стаття надійшла до редакції 07.07.2015

\section{Е. Н. Попова ${ }^{1}$, И. В. Абрашкина ${ }^{2}$, Т. С. Буракова ${ }^{1}$}

${ }^{1}$ Одесский национальный университет имени И. И. Мечникова, кафедра ботаники ул. Дворянская, 2, Одесса, 65082, Украина

${ }^{2}$ Общеобразовательная школа № 2

ул. Бендерская, 28, Измаил, Одесская обл., 68600 Украина

\section{ДЕНДРОФЛОРА ИЗМАИЛЬСКОЙ КРЕПОСТИ (Г. ИЗМАИЛ, ОДЕССКАЯ ОБЛАСТЬ, УКРАИНА)}

Проанализирован видовой состав древесных и полудревесных растений, произрастающих на территории крепости. Приводится список дендрофлоры, охватывающий 67 видов из 51 рода и 31 семейства. Ведущими семействами явля- 
ются Rosaceae и Oleaceae, ведущими родами - Acer и Tilia. Деревьев в 1.6 раза больше, чем кустарников. Доля адвентивных для Украины видов составляет $63 \%$. Растения характеризуются разнообразными полезными свойствами, информацию о которых следует использовать в экскурсионной деятельности на территории крепости. Найдено 3 вида, включенные в Красный список МСОП, состояние которых в естественных местах произрастания (за пределами Украины) приближается к угрожаемому (Aesculus hippocastanum, Juglans regia, Platycladus orientalis). Также зафиксировано 13 видов, являющихся в Украине спонтанными адвентофитами, из них 4 вида характеризуются высокой инвазийной способностью, а два являются видами-трансформерами.

Ключевые слова: дендрофлора, Измаил, крепость, Одесская область

\section{E. N. Popova ${ }^{1}$, I. V. Abrashkina ${ }^{2}$, T. S. Burakova ${ }^{1}$}

${ }^{1}$ I. I. Mechnykov Odessa National University, Department of Botany

2, Dvoryanska st., Odessa, 65082, Ukraine

${ }^{2}$ Secondary School N 2

28, Benderska st., Izmail, Odessa region, 68600 Ukraine

\section{DENDROFLORA OF THE IZMAIL FORTRESS (IZMAIL, ODESSA REGION)}

The research was carried out by traditional methods. Species names and family volumes are by Vascular plants of Ukraine checklist (Mosyakin, Fedoronchuk, 1999), life formes are by I. G. Serebryakov (1962), areas of species were classified by A. L. Takhtadzhjan (1978). 67 species from 51 genera and 31 families of the seed plants grow in the fortress. Leading families are Rosaceae (11 species), Oleaceae (6) and Aceraceae (5 species), leading genera are Acer (5 species) and Tilia (4 species). There are 39 trees, 24 shrubs and 4 half-shrubs, so trees by 1.6 times more than shrubs. Clematis jackmannii, Rubus caesius, R. idaeus and Vinca minor are half-shrubs. The proportion of exotic species for Ukraine is $63 \%$. Asian and mediterranean plants are dominated among them. Plants have a variety useful properties, information about them should be used in excursion activities in the fortress. We found out ten species from IUCN Red List: three are near threatened outside Ukraine (Aesculus hippocastanum, Juglans regia, Platycladus orientalis) and 7 species are at least concern (Betula pendula, Juniperus virginiana, Picea abies, P. pallasiana (as P. nigra subsp. pallasiana), Robinia pseudoacacia, Salix alba, Tamarix ramosissima). Also 13 species, that are spontaneous adventophytes in Ukraine were recorded, among them 12 kenophytes. Among them 4 plants are highly invasive species (Elaeagnus angustifolia, Amorpha fruticosa, Ailanthus altissima, Acer negundo) and two ones are species-transformers (Elaeagnus angustifolia and Amorpha fruticosa). Celtis occidentalis, Gleditsia triacanthos, Robinia pseudoacacia breed successfully in fortress. Distinctive feature of the Izmail fortress is small part of the spontaneus dendroflora species $(7.5 \%)$, due to the fortress located in the steppe zone.

Keywords: dendroflora, Izmail, Odessa Region 